International Journal of Applied Linguistics \& English Literature

ISSN 2200-3592 (Print), ISSN 2200-3452 (Online)

Vol. 1 No. 7; November 2012 [Special Issue on Applied Linguistics]

\title{
Gender Differences in Iranian EFL Students' Letter Writing
}

\author{
Somaye Hamdi asl \\ Islamic Azad University Najafabad Branch, Iran \\ E-mail: Somaye_hamdi@yahoo.com
}

Azizollah Dabaghi

Isfahan University, Iran

Received: 14-09- 2012

Accepted: 02-11- 2012

Published: 25-11- 2012

doi:10.7575/ijalel.v.1n.7p.155

URL: http://dx.doi.org/10.7575/ijalel.v.1n.7p.155

\begin{abstract}
Studies regarding gender differences in EFL context have been done for many years. However, it seems that writing, which is a vital skill in academic issues, has gained much less attention in this area. In addition, not having enough knowledge of gender differences for teachers is one of the main barriers of language learning. The current study examines gender differences in Iranian EFL students' letter writing in terms of 13 linguistic features mentioned in Mulac, Bradac, \& Gibbons (2001). The results of this study showed significant differences toward the use of some linguistic features. Female participants tended to use more "I" references, references to quantity, references to emotions, uncertainty verbs, sentence initial adverbials and judgmental adjectives. In addition, the results showed than women tended to be wordier than men in terms of total number of words. Men, on the other hand, exceeded women on a number of linguistic dimensions including locatives, mean length sentence and dependent clauses. Moreover, elliptical sentences were not used by female participants at all and few male participants used them in their letters. Therefore, this study demonstrated gender differences in Iranian EFL students' letter writing. These dissimilarities between genders in EFL can be contributed to many aspects such as educational instructions, teachers, and cultural differences. It also illustrated teachers' perspectives of gender regarding students' writing.
\end{abstract}

Keywords: Gender, Writing, Linguistic Features

\section{Introduction}

Writing is often considered as an integral essential element of life Swallowe (2003). It is a means both for understanding and learning. Besides, it can play a significant role in improving communication and connection among people of a society and nations. It develops self-expression and individual progress, and allows us to gather, refine, share, and preserve knowledge and understanding (Graham, 2006). Writing is considered as one of the most essential and effective tools for learning and presenting our knowledge since we start learning (Graham 2006). Those who deal with writing, frequently encounter significant obstacles in learning, work, and other life issues. Therefore, it is important to pay more attention to variables which affect writing skill including variables such as age, gender, and ethnicity.

Gender, as one of the main variables of learning, plays a vital role in writing. Halpern (2000) and Wood (2001), state that there is a link between language and gender. Therefore, men and women use language differently. The importance of knowing gender differences are even more salient in EFL context. Teachers, educators, and syllabus designers need to be aware of these differences in order to develop better teaching methods, tests, and course books.

Considering these issues, the current study is an attempt to investigate gender differences among Iranian EFL students' letter writing. 13 linguistic features mentioned in Mulac, Bradac, \& Gibbons (2001) study will be investigated in the current study. The reason behind considering these linguistic features is that Mulac \& Lundell (1994, p. 306) state the gender-link differences are more likely to be found in descriptive writing than philosophical writing. They found out that these features are used by men and women separately and differently. This study is an attempt to prove that these differences do exist in Iranian students' letter writing.

The linguistic features mentioned by Mulac, Bradac and Gibbons (2001) are as follows: 
International Journal of Applied Linguistics \& English Literature

ISSN 2200-3592 (Print), ISSN 2200-3452 (Online)

Vol. 1 No. 7; November 2012 [Special Issue on Applied Linguistics]

\subsection{Elliptical Sentences}

Crystal (1985) defines ellipsis as a sentence where "for reasons of economy, emphasis, or style, a part of the structure has been omitted, which is recoverable from a scrutiny of the context". For example, "Gorgeous! " (a beautiful snowy setting).

\subsection{Mean length sentences}

The number of words divided by the number of sentences, defined as sequences of words beginning with a capital letter and ending with a period (Mulac, et al, 2001).

\subsection{Sentence Initial Adverbials}

Emerging adverbials at the beginning of a sentence. For example, "On Monday, they went to the church."

\subsection{Dependent Clauses}

A group of words that has both a subject and a verb but (unlike an independent clause) cannot stand alone as a sentence. Also known as a subordinate clause. For example, "The crew could see the whale, which had surfaced only $50 \mathrm{~m}$ behind them."

\subsection{Judgmental Adjectives}

These indicate personal evaluation rather than merely description. For example, "distracting, nice, bothersome."

\subsection{Uncertainty verbs}

The type of verb phrases indicating apparent lack of certainty (Mulac, et al, 2001). For example, "I wonder if..., I'm not sure..., It seems....."

\subsection{Intensive Adverbs}

Adverbs which tend to give force or emphasis, such as, "very, really, quite."

\subsection{Hedges}

They are the modifiers that indicate lack of confidence in, or diminished assuredness of, the statement and also indicate lack of confidence in, or diminished assuredness of, the statement (Mulac, et al, 2001). For example, "sort of, kind of."

\subsection{References to Emotions}

Any mention of an emotion or feeling (Mulac, et al, 2001), such as "happy, enticing, depressing".

\subsection{References to Quantity}

Any mention of an amount (Mulac, et al, 2001), such as "6-8 thousand feet elevation, below 3".

\subsection{1. "I" References}

First-person singular pronoun in the subjective case (Mulac, et al, 2001).

\subsection{Locatives}

The words that indicate the location or position of objects (Mulac, et al, 2001).

\subsection{Words}

Total number of words spoken or written (Mulac, et al, 2001).

The present study has the following research questions:

1) Are there any significant differences in Iranian male and female letter writing in terms of sentences (mean length sentences, elliptical sentences), clauses and phrases (sentence initial adverbials, judgmental adjectives, dependent clauses)? If so, do they support earlier studies?

2) Are there any significant differences in Iranian male and female letter writing in terms of verb phrases (uncertainty verbs), and modifiers (intensive adverbs, hedges)? If so, do they support previous studies?

3) Are there any significant differences in Iranian male and female letter writing in terms of references (references to emotion, references to quantity, locatives and "I" references) and total number of words?

\section{Related Literature}

There have been gender differences in language use since long time ago. Studying these differences can help us shape a better world of communication. Robin Lakoff (1975) is one of the researchers that presented theories 
International Journal of Applied Linguistics \& English Literature

ISSN 2200-3592 (Print), ISSN 2200-3452 (Online)

Vol. 1 No. 7; November 2012 [Special Issue on Applied Linguistics]

regarding women's language. According to Lakoff,(1975) using more hedges, super polite forms, tag questions, empty adjectives, direct quotation are of features of women's language. She also stated that women have a special lexicon, use question intonation in declarative statements, speak less frequently, overuse qualifiers, apologize more, avoid coarse language or expletives, use indirect commands and requests, use more intensifiers and lack a sense of humor. Some researchers (e.g., Mulac,Weimann,Widenmann,\& Gibson, 1988) found that women tend to use more questions than men (e.g., "Does anyone want to get some food?"), whereas men tend to use more directives (e.g., "Let's go get some food"). In terms of mean length sentence, women are wordier than men in writing (e.g., Mulac \& Lundell, 1994; Warshay, 1972) and speaking (Mulac \& Lundell, 1986; Mulac et al., 1988; Poole, 1979).

In a study, Mulac, Seibold, \& Farris (2000) compared 36 female and 50 male managers who gave professional criticism in a role play. They found that women use more words overall and they also use longer sentences than men. Robin Lakoff (1975) is considered as a pioneer in studying gender differences in language use. She specified two types of phrases as characteristics of women language; hedges (e.g., "it seems like,") and tag questions (e.g., "... aren't you?"). Other researchers have found that women use more uncertainty verbs and "I" references in writing (Mulac \& Lundell, 1994) and speech (Hartman, 1976; Poole, 1979). However, their conclusion was based on only two studies: one representing analyses of 32 essays (4th-grader sample; Mulac et al., 1990), one representing 148 essays (Mulac \& Lundell, 1994), and both used relatively impersonal writing tasks (essays and descriptions of photographs). Certainly, if the entire category of personal pronouns is considered, women frequently are the higher users (Gleser et al., 1959; Mulac \& Lundell, 1986). Mehl and Pennebaker (2003) proposed that women tend to use more references to positive emotion, whereas men refer more to anger. This finding was in line with the study of Mulac, Bradac, and Gibbons(2001) in which men used more judgmental adjectives but women used more sentence initial adverbials. There have been very few studies regarding gender differences in EFL writing. Sunderland (2000) cited one study that was done by L.A. Morris. According to Morris (1998), female ESL writers surpass their male counterparts in writing. Morris also found that both genders' texts were comparable regarding accuracy and readability. Her study was conducted in a social context and she did not mention about classroom context.

In second language contexts, differences in native speaker status and cultural background frequently reach into the classroom; often the teacher is a native speaker and does not share the students' cultural background, whereby the students themselves may represent a culturally (and perhaps even socio-economically) diverse group. In foreign language classrooms, by contrast, many teachers share the first language and cultural background of a generally quite homogeneous student body. Therefore, special care must be taken not to combine issues of gender, native speaker status, pragmatic competence and students' culture (or to combine them very carefully). These requirements lay further emphasis on how desirable it may be to distinguish between second and foreign language settings. Gender may be observed more easily as a distinct variable in a foreign language context. There, issues of native speaker status and biculturalism (at least at the earlier stages of learning) are less prominent. Clearly, studies of second language acquisition serve as valuable sources to help identify the direction of research in foreign language learning, but at the same time, they cannot speak clearly of gender issues in the foreign language classroom. Also in foreign language settings, learners depend much more on the classroom for interactional opportunities, i.e., the chance to use the language in a meaningful and contextual manner. As Brooks (1993) summarizes: "The formal classroom setting is, in many cases, the only place where any kind of social interaction in the foreign language is made available. It is in this environment that the language and communication are to be learned".

\section{Methodology}

\subsection{Participants}

For this study, 64 Iranian EFL learners (30 males and 34 females) were selected randomly. Participants were MA students majored in English. The students were all at the same major, same level, and had passed similar courses in writing. They were all native speakers of Farsi. In order to avoid generation-related differences, participants were between 24 to 30 years of age. Finally, factors such as social class and ethnicity which could not be established, from the contents in the letters, were disregarded.

\subsection{Instruments}

The instruments employed in this study were a standard proficiency test (Oxford Placement Test to find homogenous students based on proficiency level and Roebuck's analytic scoring Rubric modified by Maftoon \& Rabiee (2006) for rating students' paragraphs. 
International Journal of Applied Linguistics \& English Literature

ISSN 2200-3592 (Print), ISSN 2200-3452 (Online)

Vol. 1 No. 7; November 2012 [Special Issue on Applied Linguistics]

\subsection{Procedure}

OPT will be administered to ensure the participants' homogeneity. The proficiency test, OPT, was run and participants at the intermediate level were selected. A questionnaire was administered to collect background data of students' writing. In the next session, the researcher asked selected students to write a letter of complaint (complaining about poor facilities of a hotel). Complaining letter was chosen according to these factors and criteria: a) it should be far from gender bias. It is based on the level of students' knowledge; b) it should be based on students' experience in writing; c) The students need to be interested in writing about the topic.

Also, the topic was chosen because it involved description, which implies the use of adjectives. Letters written by male and female students were collected in order to compare the students' writing and also to get material that could be used in the questionnaires.

\subsection{Data analysis}

All the linguistic features used in this study by the researcher are Elliptical sentences, Mean length sentences, Sentence-initial adverbials, Dependent clauses, Judgmental adjectives, , Intensive adverbs, Hedges, Uncertainty verbs, References to emotion, References to quantity, Locatives, "I" references, Total number of words. As stated in the introduction, these features have been chosen in this study because according to Mulac and Lundel (1994) these features are more likely to be found in descriptive writing. These features are specified and counted by the researcher according to the letters and all of them were observed by a linguist. All the identified features were revised by an expert in relevant field to make sure of accuracy of the selected features.

\section{Results and Discussion}

In order to answer the first research question of the study, the differences between male $(n=30)$ and female participants $(n=34)$ in 64 letters were analyzed based on 13 linguistic features. Therefore, thirteen t-tests were performed as follows:

Table 1. Independent Samples Test on gender of participants and number of words in writing

\begin{tabular}{|c|c|c|c|c|c|c|c|c|c|c|}
\hline & & \multicolumn{4}{|c|}{$\begin{array}{l}\text { Levene's Test } \\
\text { for Equality of } \\
\text { Variances }\end{array}$} & \multicolumn{5}{|c|}{ t-test for Equality of Means } \\
\hline & & \multirow[t]{2}{*}{$\mathrm{F}$} & \multirow[t]{2}{*}{ Sig. } & \multirow[t]{2}{*}{$\mathrm{t}$} & \multirow[t]{2}{*}{$\mathrm{df}$} & \multirow{2}{*}{$\begin{array}{l}\text { Sig. } \\
\text { (2-tail } \\
\text { ed) }\end{array}$} & \multirow{2}{*}{$\begin{array}{l}\text { Mean } \\
\text { Difference }\end{array}$} & \multirow{2}{*}{$\begin{array}{l}\text { Std.Error } \\
\text { Difference }\end{array}$} & \multicolumn{2}{|c|}{$\begin{array}{c}95 \% \text { Confidence Interval } \\
\text { of the Difference }\end{array}$} \\
\hline & & & & & & & & & Lower & Upper \\
\hline \multirow{2}{*}{$\begin{array}{l}\text { Number } \\
\text { Of } \\
\text { Words }\end{array}$} & $\begin{array}{l}\text { Equal } \\
\text { variances } \\
\text { assumed }\end{array}$ & 1.214 & .275 & -1.44 & 62 & .154 & -48.38039 & 33.48432 & -115.31460 & 18.55382 \\
\hline & $\begin{array}{l}\text { Equal } \\
\text { variances } \\
\text { not assumed }\end{array}$ & & & -1.48 & 57.36 & .144 & -48.38039 & 32.64073 & -113.73326 & 16.97247 \\
\hline
\end{tabular}

The first t-test was performed to show whether there is any significant difference between males and females regarding the total number of words. The results in Table 1 indicated that there is no significant difference $(t=$ $-1.44, p=.15$, sig $=0.275$ ) between males and females regarding this linguistic feature. These findings are not consistent with the study of Mulac, Bradac and Gibbons (2001), which revealed that women are wordier than men in terms of total number of words. The present study shows that male participants used more words than female participants. This can be due to more knowledge of vocabulary.

To detect the difference between males and females regarding the use of hedging, another t-test was performed. The results in Table 4.4 indicated that there is a significant difference between males and females regarding this linguistic feature $(t=-2.91, p=.005$, sig $=0.017)$. Female participants used more hedges than male participants. Similarly, Mulac, Bradac and Gibbons (2001) in their study stated that women tend to use more hedges than men. According to Lakoff (1975), using hedges is an index of apology. Women do not want to force their ideas on another person. 
International Journal of Applied Linguistics \& English Literature

ISSN 2200-3592 (Print), ISSN 2200-3452 (Online)

Vol. 1 No. 7; November 2012 [Special Issue on Applied Linguistics]

Table 2. Independent Samples Test on gender of participants and Hedge in writing

Levene's Test

for Equality

t-test for Equality of Means

of Variances

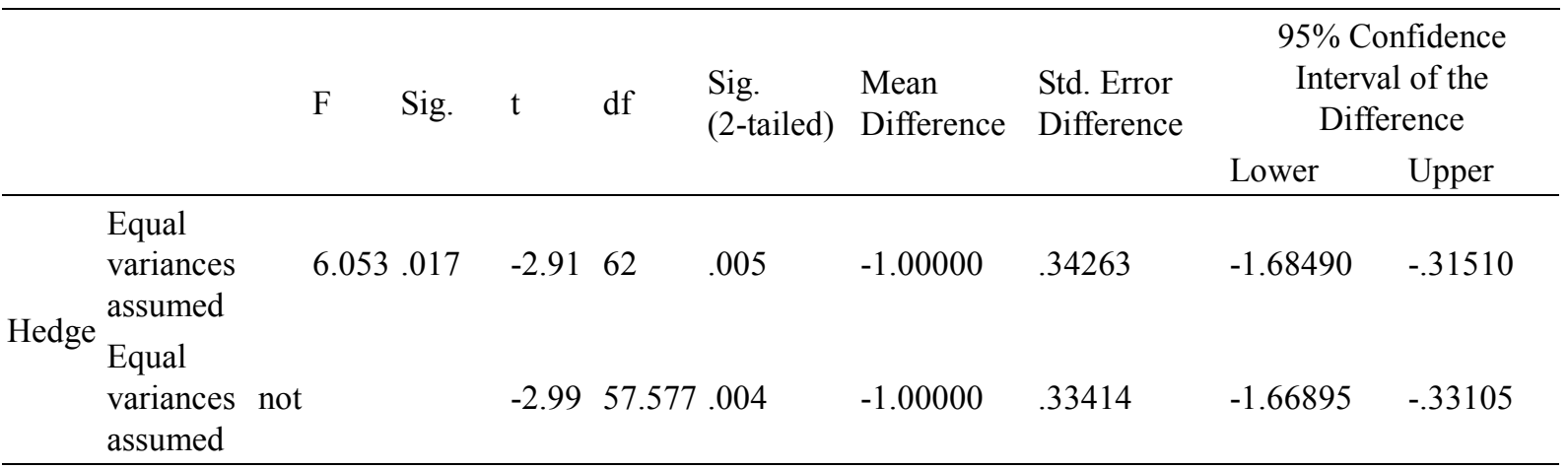

Table 3. Independent Samples Test on gender of participants and "I" references in writing

\begin{tabular}{|c|c|c|c|c|c|c|c|c|c|c|}
\hline & & $\begin{array}{r}\text { Leve } \\
\text { for } \mathrm{E} \\
\mathrm{Va}\end{array}$ & $\begin{array}{l}\text { ne's Tes } \\
\text { juality } \\
\text { iances }\end{array}$ & & & & t-te & st for Equal & $y$ of Means & \\
\hline & & $\mathrm{F}$ & Sig. & $\mathrm{t}$ & df & Sig. & $\begin{array}{l}\text { Mean } \\
\text { Difference }\end{array}$ & $\begin{array}{l}\text { Std. Error } \\
\text { Difference }\end{array}$ & $\begin{array}{r}95 \% \\
\text { Inter } \\
\mathrm{Di}\end{array}$ & $\begin{array}{l}\text { nfidence } \\
\text { l of the } \\
\text { rence }\end{array}$ \\
\hline & & & & & & & & & Lower & Upper \\
\hline \multirow{2}{*}{ "I" Reference } & $\begin{array}{l}\text { Equal } \\
\text { variances } \\
\text { assumed }\end{array}$ & .004 & .950 & -3.98 & 62 & .000 & -4.71765 & 1.18380 & -7.08402 & -2.35127 \\
\hline & $\begin{array}{l}\text { Equal } \\
\text { variances } \\
\text { not assumed }\end{array}$ & & & -4.05 & 60.53 & .000 & -4.71765 & 1.16306 & -7.04369 & -2.39161 \\
\hline
\end{tabular}

The result of t-test on the use of "I" references for the male and female participants showed that they were significantly different $(t=-2.91, p=.005$, sig $=0.950)$ from each other in this linguistic feature at the level of .01(see Table 3). Women used more "I" references than men. Findings of this study were in contrast with the study of Mulac, Bradac and Gibbons (2001). Bucci \& Freedman, (1981); Rude, Gortner, \& Pennebaker, (2004); Weintraub, (1981) stated that depressed people use more first-person singular pronouns. Therefore, using more "I" references by women can be due to this fact.

Table 4. Independent Samples Test on gender of participants and Sentence Initial Adverbial in writing

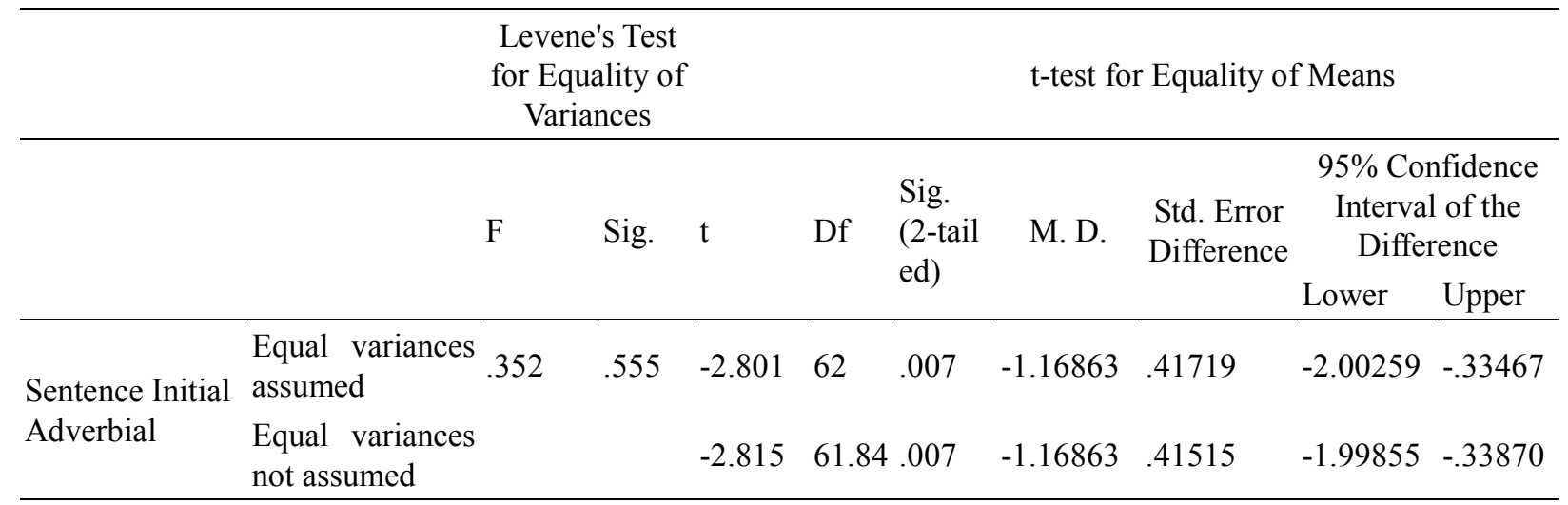




\section{International Journal of Applied Linguistics \& English Literature \\ ISSN 2200-3592 (Print), ISSN 2200-3452 (Online)}

Vol. 1 No. 7; November 2012 [Special Issue on Applied Linguistics]

Another t-test was performed to show whether there is any significant difference between males and females regarding the use of sentence initial adverbials in letters. The results in Table 4 revealed that there is significant difference $(t=-2.80, p=.007$, sig $=0.555)$ between males and females regarding this linguistic feature. Female participants used more sentence initial adverbials than male participants. Similarly, Mulac, Bradac and Gibbons (2001) in their study found out that women tend to use more sentence initial adverbials than men. As Chafe (1987:38), Fries (1981/1983, 1995), Daneš (1974), Enkvist (1981, 1984), Virtanen (1992), Ventola (1995), Mauranen (1996), Svensson (2000) stated, using sentence initial adverbials at discourse level means that the writer wants to fit the sentence in its situational or textual context .

Table 5. Independent Samples Test on gender of participants and Elliptical sentences in writing

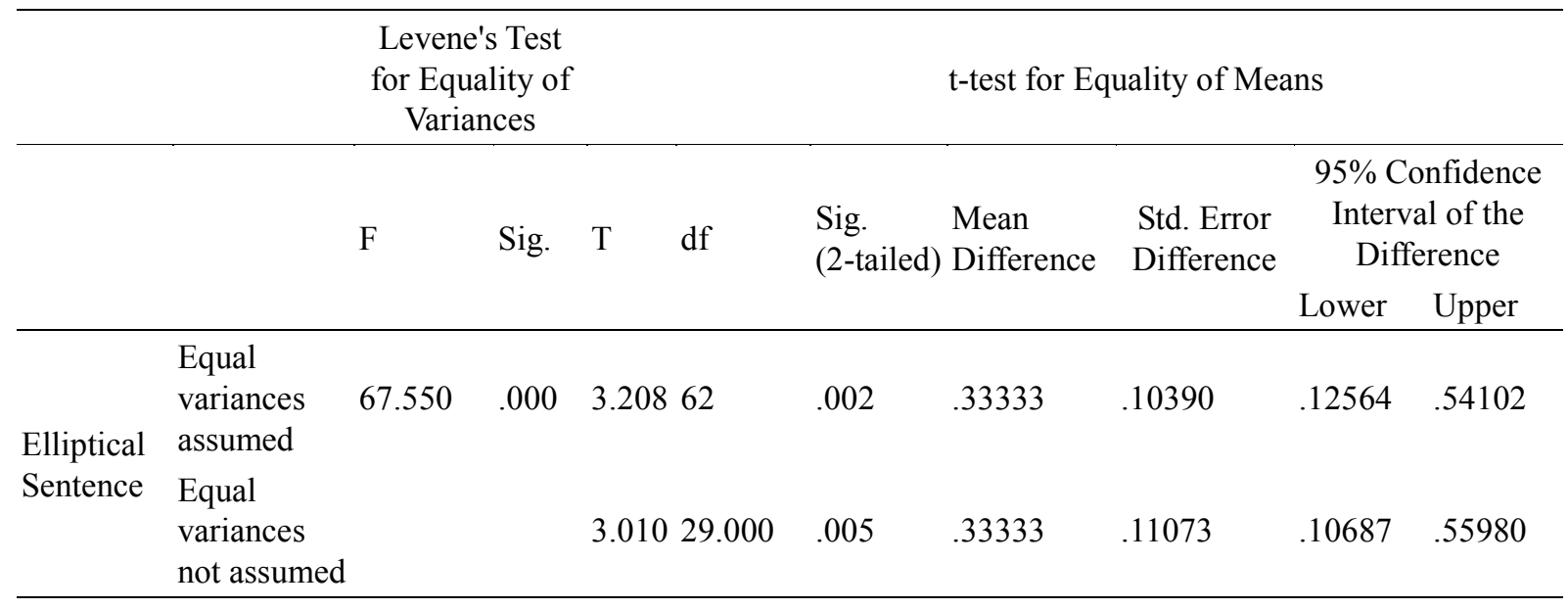

The results of t-test on the males and females' letters regarding the use of elliptical sentences showed that there is a significant difference $(t=-3.20, p=.002$, sig $=0.000)$ between males and females. (see Table 5). Male participants used more elliptical sentences than female participants. Similarly, Mulac, Bradac and Gibbons in their study stated that men tend to use more elliptical sentences than women.

Table 6. Independent Samples Test on gender of participants and length of sentences in writing

\begin{tabular}{|c|c|c|c|c|c|c|c|c|c|c|}
\hline & & \multicolumn{4}{|c|}{$\begin{array}{l}\text { Levene's Test } \\
\text { for Equality of } \\
\text { Variances }\end{array}$} & \multicolumn{5}{|c|}{ t-test for Equality of Means } \\
\hline & & \multirow[t]{2}{*}{$\mathrm{F}$} & \multirow[t]{2}{*}{ Sig. } & \multirow[t]{2}{*}{$\mathrm{t}$} & \multirow[t]{2}{*}{ Df } & \multirow{2}{*}{$\begin{array}{l}\text { Sig. } \\
\text { (2-taile } \\
\text { d) }\end{array}$} & \multirow[t]{2}{*}{$\begin{array}{l}\text { Mean } \\
\text { Difference }\end{array}$} & \multirow[t]{2}{*}{$\begin{array}{l}\text { Std. Error } \\
\text { Difference }\end{array}$} & \multicolumn{2}{|c|}{$\begin{array}{l}95 \% \text { Confidence } \\
\text { Interval of the } \\
\text { Difference }\end{array}$} \\
\hline & & & & & & & & & Lower & Upper \\
\hline \multirow{2}{*}{$\begin{array}{l}\text { Mean Length } \\
\text { Sentence }\end{array}$} & $\begin{array}{l}\text { Equal } \\
\text { variances } \\
\text { assumed }\end{array}$ & .328 & .569 & -.978 & 62 & .332 & -1.01306 & 1.03567 & -3.08334 & 1.05722 \\
\hline & $\begin{array}{l}\text { Equal } \\
\text { variances not } \\
\text { assumed }\end{array}$ & & & -.960 & 53.007 & .341 & -1.01306 & 1.05495 & -3.12902 & 1.10291 \\
\hline
\end{tabular}

The results of t-test on the males and females' letters regarding mean length sentence showed that there is no significant difference $(t=-.97, p=.332$, sig $=0.569)$ between males and females. (see Table 6$)$. The findings of this study is inconsistent with the study of Mulac, Bradac and Gibbons (2001) which stated that women are wordier than men in terms of mean length sentence. Longer sentences indicate higher proficiency level and knowledge of grammar. In the present study both male and female participants' sentences had almost the same length.

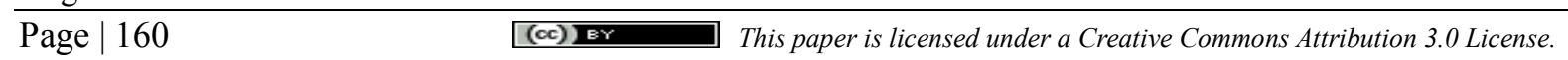


International Journal of Applied Linguistics \& English Literature

ISSN 2200-3592 (Print), ISSN 2200-3452 (Online)

Vol. 1 No. 7; November 2012 [Special Issue on Applied Linguistics]

Table 7. Independent Samples Test on gender of participants and dependent clauses in writing

\begin{tabular}{|c|c|c|c|c|c|c|c|c|c|}
\hline & & $\begin{array}{c}\text { Levene's Test for } \\
\text { Equality of } \\
\text { Variances }\end{array}$ & & & & t-test for Eql & lity of Means & & \\
\hline & & Sig. & $\mathrm{t}$ & $\mathrm{df}$ & $\begin{array}{l}\text { Sig. } \\
\text { (2-tailed) }\end{array}$ & $\begin{array}{l}\text { Mean } \\
\text { Difference }\end{array}$ & $\begin{array}{l}\text { Std. Error } \\
\text { Difference }\end{array}$ & $\begin{array}{r}95 \% \mathrm{C} \\
\text { Inter } \\
\text { Dif }\end{array}$ & $\begin{array}{l}\text { onfidence } \\
\text { al of the } \\
\text { erence }\end{array}$ \\
\hline & & & & & & & & Lower & Upper \\
\hline \multirow{2}{*}{$\begin{array}{l}\text { Dependent } \\
\text { Clause }\end{array}$} & $\begin{array}{l}\text { Equal } \\
\text { variances } \\
\text { assumed }\end{array}$ & 7.451 .008 & 2.812 & 62 & .007 & 1.17647 & .41835 & .34019 & 2.01275 \\
\hline & $\begin{array}{l}\text { Equal } \\
\text { variances } \\
\text { not assumed }\end{array}$ & & 2.697 & 39.395 & .010 & 1.17647 & .43621 & .29444 & 2.05851 \\
\hline
\end{tabular}

A t-test was performed to show whether there is any significant difference between males and females regarding the use of dependent clauses in letters. The results in Table 7 revealed that there is a significant difference $(\mathrm{t}=$ $-2.81, \mathrm{p}=.007$, sig $=0.008$ ) between males and females regarding this linguistic feature. Men used more dependent clauses than women. The findings of this study were not consistent with the study of Mulac, Bradac and Gibbons (2001).

Table 8. Independent Samples Test on gender of participants and adjectives in writing

\begin{tabular}{|c|c|c|c|c|c|c|c|c|c|}
\hline & & $\begin{array}{r}\text { Lev } \\
\text { for } \mathrm{E} \\
\mathrm{Vc}\end{array}$ & $\begin{array}{l}\text { ene's T } \\
\text { qualit } \\
\text { riance }\end{array}$ & & & & t-test for & Equality of & Means \\
\hline & & $\mathrm{F}$ & Sig. & $\mathrm{T}$ & Df & $\begin{array}{l}\text { Sig. } \\
\text { (2-tailed) }\end{array}$ & $\begin{array}{l}\text { Mean } \\
\text { Difference }\end{array}$ & $\begin{array}{l}\text { Std. Error } \\
\text { Difference }\end{array}$ & $\begin{array}{l}95 \% \text { Confidence } \\
\text { Interval of the } \\
\text { Difference }\end{array}$ \\
\hline & & & & & & & & & Lower Upper \\
\hline \multirow{2}{*}{$\begin{array}{l}\text { Judgmental } \\
\text { Adjective }\end{array}$} & $\begin{array}{l}\text { Equal variances } \\
\text { assumed }\end{array}$ & 2.806 & .099 & -1.93 & 62 & .058 & -1.42745 & .73824 & -2.90317 .04827 \\
\hline & $\begin{array}{l}\text { Equal variances } \\
\text { not assumed }\end{array}$ & & & -2.03 & 39.6 & .048 & -1.42745 & .70011 & $-2.84287-.01203$ \\
\hline
\end{tabular}

In order to see the difference between males and females' letters regarding the use of judgmental adjectives, another t-test was performed. The results in Table 8 indicated that there is no significant difference between males and females regarding this linguistic feature $(t=-1.93, p=.05$, sig $=0.099)$. Mulac, Bradac and Gibbons, in their study stated that men tend to use more judgmental adjectives than women. 
International Journal of Applied Linguistics \& English Literature

ISSN 2200-3592 (Print), ISSN 2200-3452 (Online)

Vol. 1 No. 7; November 2012 [Special Issue on Applied Linguistics]

Table 9. Independent Samples Test on gender of participants and adjectives in writing

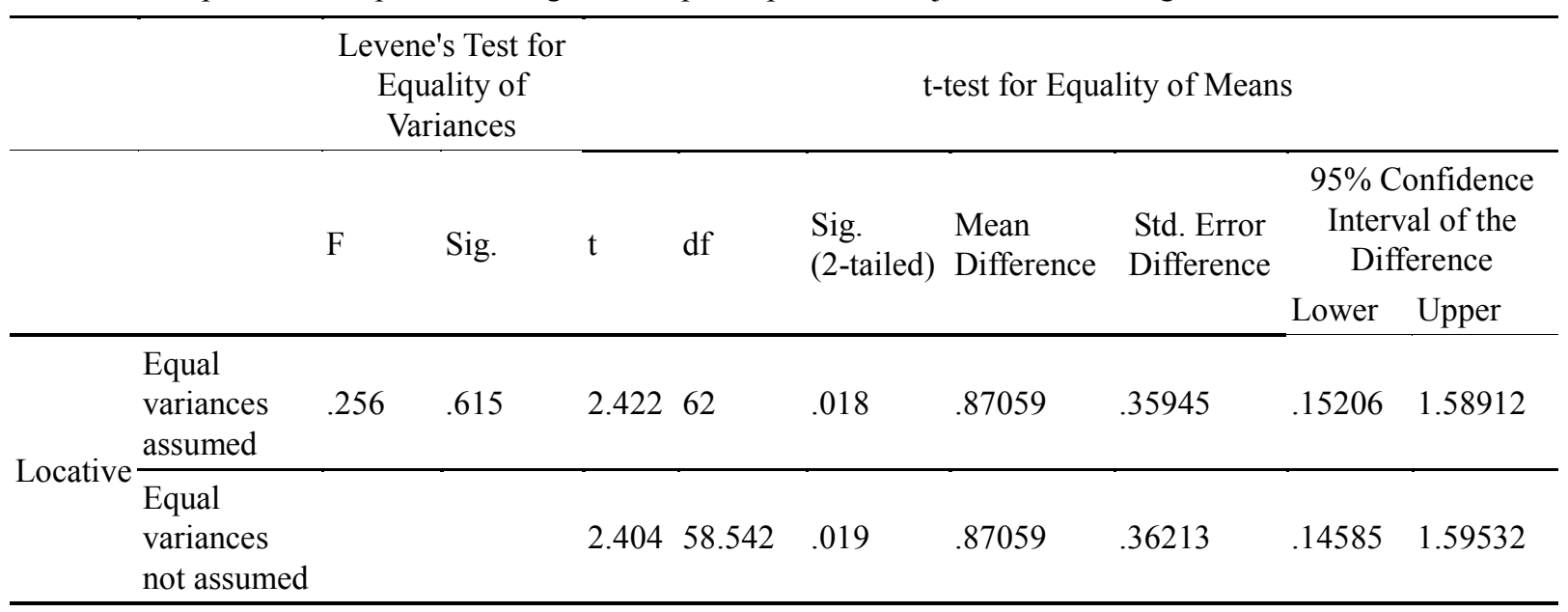

A t-test was done to show whether there is any significant difference between males and females regarding the use of locatives in their letters. The results in Table 9 indicated that there is a significant difference $(t=-2.42, p$ $=.01$, sig $=0.615)$ between males and females regarding this linguistic feature. Male participants used more locatives than female participants. The findings of the present study were in line with the study of Mulac, Bradac and Gibbons (2001).

Table 10. Independent Samples Test on gender of participants and reference to quantity in writing

\begin{tabular}{|c|c|c|c|c|c|c|c|c|c|}
\hline & & $\begin{array}{l}\text { Levene's } \\
\text { Test for } \\
\text { Equality o } \\
\text { Variances }\end{array}$ & & & & & \multicolumn{3}{|c|}{ t-test for Equality of Means } \\
\hline & & \multirow[t]{2}{*}{ Sig. } & \multirow[t]{2}{*}{$\mathrm{t}$} & \multirow[t]{2}{*}{ Df } & \multirow[t]{2}{*}{$\begin{array}{l}\text { Sig. } \\
\text { (2-tailed) }\end{array}$} & \multirow[t]{2}{*}{$\begin{array}{l}\text { Mean } \\
\text { Difference }\end{array}$} & \multirow[t]{2}{*}{$\begin{array}{l}\text { Std. Error } \\
\text { Difference }\end{array}$} & \multicolumn{2}{|c|}{$\begin{array}{l}95 \% \text { Confidence } \\
\text { Interval of the } \\
\text { Difference }\end{array}$} \\
\hline & & & & & & & & Lower & Upper \\
\hline Reference & $\begin{array}{l}\text { Equal variances } \\
\text { assumed }\end{array}$ & .163 .688 & -2.29 & 62 & .025 & -1.50980 & .65783 & -2.82480 & -.19481 \\
\hline Quantity & $\begin{array}{l}\text { Equal variances } \\
\text { not assumed }\end{array}$ & & -2.35 & 57.684 & .022 & -1.50980 & .64168 & -2.79441 & -.22520 \\
\hline
\end{tabular}

Another t-test was calculated to show whether there is any significant difference between males and females regarding the use of references to quantity. The results in Table 10 indicated that there is no significant difference $(\mathrm{t}=-2.29, \mathrm{p}=.02$, sig $=0.688)$ between males and females regarding this linguistic feature. The findings of this study were in contrast with the study of Mulac, Bradac and Gibbons (2001) which stated that men use more references to quantity than women. 
International Journal of Applied Linguistics \& English Literature

ISSN 2200-3592 (Print), ISSN 2200-3452 (Online)

Vol. 1 No. 7; November 2012 [Special Issue on Applied Linguistics]

Table 11. Independent Samples Test on gender of participants and reference to emotion in writing

\begin{tabular}{|c|c|c|c|c|c|c|c|c|c|c|}
\hline & & $\begin{array}{l}\text { Leven } \\
\text { for Ec } \\
\text { of Var }\end{array}$ & $\begin{array}{l}\text { 's Test } \\
\text { uality } \\
\text { ances }\end{array}$ & & & & \multicolumn{4}{|c|}{ t-test for Equality of Means } \\
\hline & & \multirow[t]{2}{*}{$\mathrm{F}$} & \multirow[t]{2}{*}{ Sig. } & \multirow[t]{2}{*}{$\mathrm{t}$} & \multirow[t]{2}{*}{ Df } & \multirow[t]{2}{*}{$\begin{array}{l}\text { Sig. } \\
\text { (2-tailed) }\end{array}$} & \multirow[t]{2}{*}{$\begin{array}{l}\text { Mean } \\
\text { Difference }\end{array}$} & \multicolumn{3}{|c|}{$\begin{array}{lc} & 95 \% \text { Confidence } \\
\text { Std. Error } & \text { Interval of the } \\
\text { Difference } & \text { Difference }\end{array}$} \\
\hline & & & & & & & & & Lower & Upper \\
\hline \multirow{2}{*}{$\begin{array}{l}\text { Reference } \\
\text { To } \\
\text { Emotion }\end{array}$} & $\begin{array}{l}\text { Equal } \\
\text { variances } \\
\text { assumed }\end{array}$ & 1.161 & .285 & -4.42 & 62 & .000 & -1.09804 & .24802 & -1.59383 & -.60225 \\
\hline & $\begin{array}{l}\text { Equal } \\
\text { variances } \\
\text { not assumed }\end{array}$ & & & -4.52 & 59.4 & .000 & -1.09804 & .24289 & -1.58398 & -.61210 \\
\hline
\end{tabular}

T-test was performed to show whether there is any significant difference between males and females regarding the use of references to emotion. The results in Table 11 indicated that there is a significant difference $(t=-2.29$, $p=.00$, sig $=0.285$ ) between males and females regarding this linguistic feature. Women used more references to emotion than men. The findings of this study were consistent with the study of Mulac, Bradac and Gibbons (2001).

Table 12. Independent Samples Test on gender of participants and reference to emotion in writing

\begin{tabular}{|c|c|c|c|c|c|c|c|c|c|}
\hline & & $\begin{array}{l}\text { Levene's } \\
\text { Test for } \\
\text { Equality of } \\
\text { Variances }\end{array}$ & & & & \multicolumn{4}{|c|}{ t-test for Equality of Means } \\
\hline & & \multirow[t]{2}{*}{ Sig. } & \multirow[t]{2}{*}{$\mathrm{t}$} & \multirow[t]{2}{*}{ Df } & \multirow[t]{2}{*}{$\begin{array}{l}\text { Sig. } \\
\text { (2-tailed) }\end{array}$} & \multirow[t]{2}{*}{$\begin{array}{l}\text { Mean } \\
\text { Difference }\end{array}$} & \multirow[t]{2}{*}{$\begin{array}{l}\text { Std. Error } \\
\text { Difference }\end{array}$} & \multicolumn{2}{|c|}{$\begin{array}{l}95 \% \text { Confidence } \\
\text { Interval of the } \\
\text { Difference }\end{array}$} \\
\hline & & & & & & & & Lower & Upper \\
\hline \multirow{2}{*}{$\begin{array}{l}\text { Intensive } \\
\text { Adverb }\end{array}$} & $\begin{array}{l}\text { Equal } \\
\text { variances } \\
\text { assumed } \\
\end{array}$ & 5.431 .023 & -3.018 & 62 & .004 & -1.41176 & .46780 & -2.34688 & -.47665 \\
\hline & $\begin{array}{l}\text { Equal } \\
\text { variances not } \\
\text { assumed }\end{array}$ & & -3.117 & 53.509 & .003 & -1.41176 & .45290 & -2.31996 & -.50357 \\
\hline
\end{tabular}

The result of t-test on the differences between males and females regarding the use of intensive adverbs, as is shown in Table 12, indicated that there is a significant difference $(t=-3.01, p=.004$, sig $=0.023)$ between males and females regarding this linguistic feature. Female participants use more intensive adverbs than male participants. The findings of this study were consistent with the study of Mulac, Bradac and Gibbons (2001). 
International Journal of Applied Linguistics \& English Literature

ISSN 2200-3592 (Print), ISSN 2200-3452 (Online)

Vol. 1 No. 7; November 2012 [Special Issue on Applied Linguistics]

Table 13. Independent Samples Test on gender of participants and using uncertainty verb in writing

\begin{tabular}{|c|c|c|c|c|c|c|c|c|c|}
\hline & & \multicolumn{3}{|c|}{$\begin{array}{l}\text { Levene's Test } \\
\text { for Equality of } \\
\text { Variances }\end{array}$} & \multicolumn{5}{|c|}{ t-test for Equality of Means } \\
\hline & & $\mathrm{F}$ & Sig. & $\mathrm{t}$ & df & $\begin{array}{l}\text { Sig. } \\
\text { (2-tailed) }\end{array}$ & $\begin{array}{l}\text { Mean } \\
\text { Difference }\end{array}$ & $\begin{array}{l}\text { Std. Error } \\
\text { Difference }\end{array}$ & $\begin{array}{c}95 \% \text { Confidence } \\
\text { Interval of the } \\
\text { Difference }\end{array}$ \\
\hline \multirow[t]{2}{*}{$\begin{array}{l}\text { Uncertainty } \\
\text { Verb }\end{array}$} & $\begin{array}{l}\text { Equal } \\
\text { variances } \\
\text { assumed }\end{array}$ & .931 & .338 & -5.377 & 62 & .000 & -1.29804 & .24140 & $\begin{array}{lll}-1.78060 & -.81548\end{array}$ \\
\hline & $\begin{array}{l}\text { Equal } \\
\text { variances } \\
\text { not } \\
\text { assumed }\end{array}$ & & & -5.401 & 61.791 & .000 & -1.29804 & .24035 & $-1.77853-.81755$ \\
\hline
\end{tabular}

Finally, the t-test between the gender of participants and their use of uncertainty verbs were calculated. The results in Table 13 showed that there is a significant difference between males and females in terms of this linguistic feature $(\mathrm{sig}=0.338$. Female participants used uncertainty verbs more than male participants. The findings regarding this t-test are in line with the study of Mulac, Bradac and Gibbons (2001). This can be due to lack of enough self-confidence in women.

\section{Conclusion}

Based on the results, it was found that there are gender differences in Iranian EFL letter writing, but only some of them are significant. The stereotyped picture of women regarding them using emotional language was depicted in their writing in this study. One reason can be due to the fact that in the present study, the genre of writing was descriptive. Both genders used almost all of the features more or less. But elliptical sentences were not used by female participants at all and few male participants used them in their letters. Also, dependent clause is one of the linguistic features that were not applied as much as others.

Researchers (Lakoff, 1975; Tannen, 1990; Holmes, 1993; Mulac, Bradac, \& Gibbons, 2001) have proposed the idea that there are some differences between male and female language. These differences were mentioned in the literature review. The findings from the current study supported what they proposed regarding the existence of these differences in EFL writing. Therefore, this study demonstrated gender differences in Iranian EFL students' letter writing. These dissimilarities between genders in EFL can be contributed to many aspects such as educational instructions, teachers, and cultural differences. It also illustrated teachers' perspectives of gender regarding students' writing.

\section{References}

Brooks, J. G., \& Brooks, M. G. (1993). In search of understanding: The case for constructivist classrooms. Alexandria, VA: Association of Supervision and Curriculum Development

Gleser,G. C., Gottschalk, L. A., \& John, W. (1959). The relationship of sex and intelligence to choice of words: A normative study of verbal behavior. Journal of Clinical Psychology, 15, 183-191.

Graham, S. (2006). Strategy instruction and the teach-ing of writing: a meta-analysis. In MacArthur, C. A., Graham, S., \& Fitzgerald, J. (Eds.), Handbook of writ-ing research (pp. 187-207). New York, NY: Guilford Press.

Halpern, D. F. (2000). Sex differences in cognitive abilities (3rd ed.). Mahwah, NJ: Erlbaum. Wood, J. T. (2001). Gendered lives: Communication, gender, and culture (4th ed.). Belmont, CA: Wadsworth

Hartman, M. (1976). A descriptive study of the language of men and women born in Maine around 1900 as it reflects the Lakoff hypotheses in language and woman's place. In B. L. Dubois \& I. Crouch (Eds.), The sociology of the languages of American women (pp. 81-90). San Antonio, TX: Trinity University Press.

Page | $164 \quad$ This paper is licensed under a Creative Commons Attribution 3.0 License. 


\section{International Journal of Applied Linguistics \& English Literature ISSN 2200-3592 (Print), ISSN 2200-3452 (Online) \\ Vol. 1 No. 7; November 2012 [Special Issue on Applied Linguistics]}

Lakoff, R. (1975). Language and women's place. New York, NY: Harper and Row.

Mehl, M. R., \& Pennebaker, J. W. (2003). The sounds of social life: A psychometric analysis of students' daily social environments and natural conversations. Journal of Personality\&Social Psychology, 84, 857-870.

Morris, L.A. 1998. Differences in men's and women's ESL writing at the junior college level: consequences for research on feedback. The Canadian Modern Language Review/ La Revue canadienne des langues vivantes 55/2: 219-38.

Mulac, A., Bardac, J. J., \& Gibbons, P. 2001. Empirical support for the 'gender as culture' hypothesis: An intercultural analysis of male/female language differences. Human Communication Research, 27, 121-152.

Mulac, A., \& Lundell, T. L. (1986). Linguistic contributors to the gender-linked language effect. Journal of Language \& Social Psychology, 5, 81-101.

Mulac, A., Seibold, D. R., \& Farris, J. L. (2000). Female and male managers' and professionals' criticism giving: Differences in language use and effects. Journal of Language \& Social Psychology, 19(4), 389-415.

Mulac, A., Studley, L. B., \& Blau, S. (1990). The gender-linked effect in primary and secondary students' impromptu essays. Sex Roles, 23, 439-469.

Mulac, A., Wiemann, J. M., Widenmann, S. J., \& Gibson, T. W. (1988). Male/female language differences and effects in same-sex and mixed-sex dyads: The gender-linked language effect. Communication Monographs, 55 , $315-335$.

Poole, M. E. (1979). Social class, sex, and linguistic coding. Language and Speech, 22, 4967.

Sunderland, J. 2000. Issues of language and gender in second and foreign language education. Language Teaching 33: 203-223

Swallowe, J. (2003). A critical review of research into differences between men and women

in the use of media for interpersonal communication. Retrieved June 23, 2007, from

http://www.aber.ac.uk/media/students/jos olo2.doc

Wood, J. T. (2001). Gendered lives: Communication, gender, and culture (4th ed.). Belmont, CA: Wadsworth.

\section{Appendix 1}

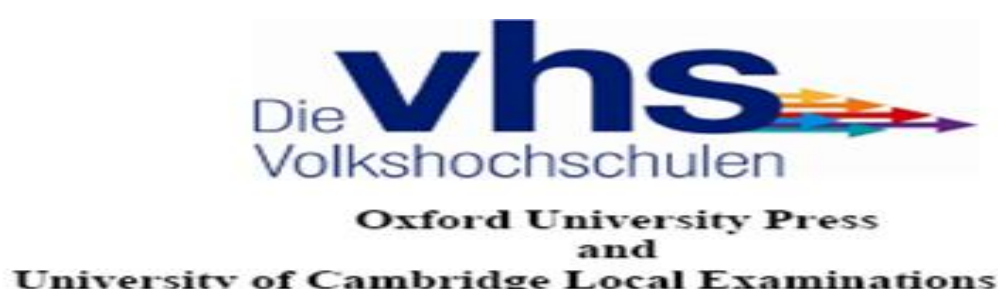

University of Cambridge Local Examinations Syndicate

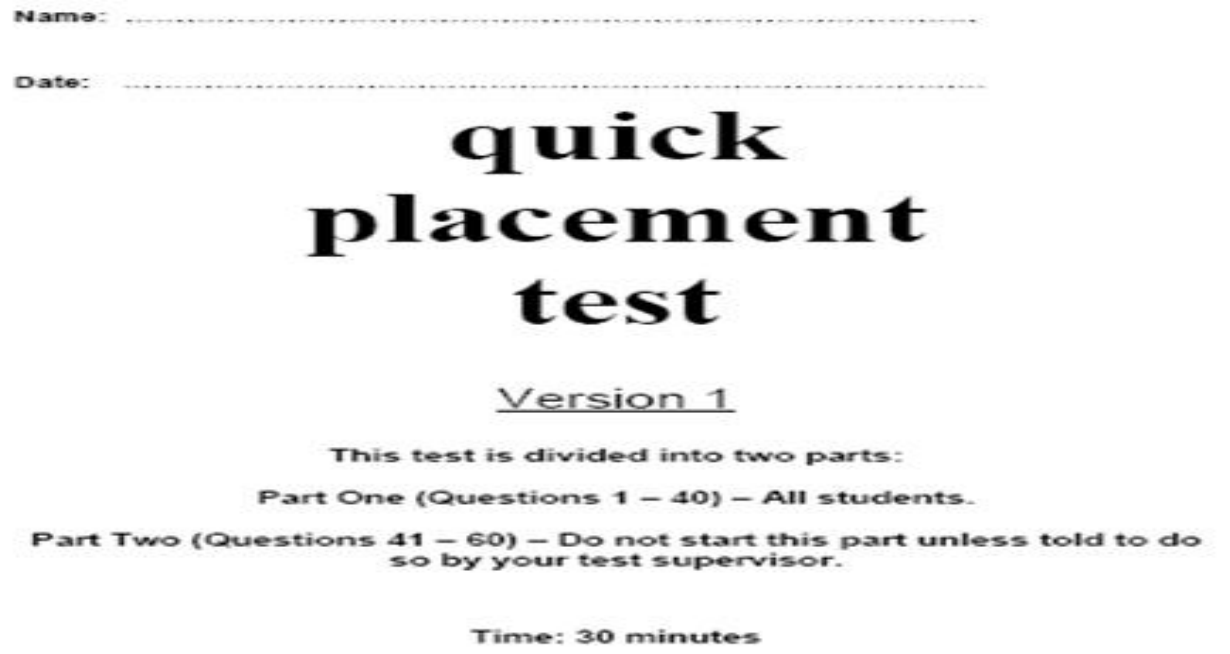

Page | 165 


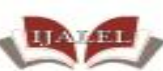

International Journal of Applied Linguistics \& English Literature

ISSN 2200-3592 (Print), ISSN 2200-3452 (Online)

Vol. 1 No. 7; November 2012 [Special Issue on Applied Linguistics]

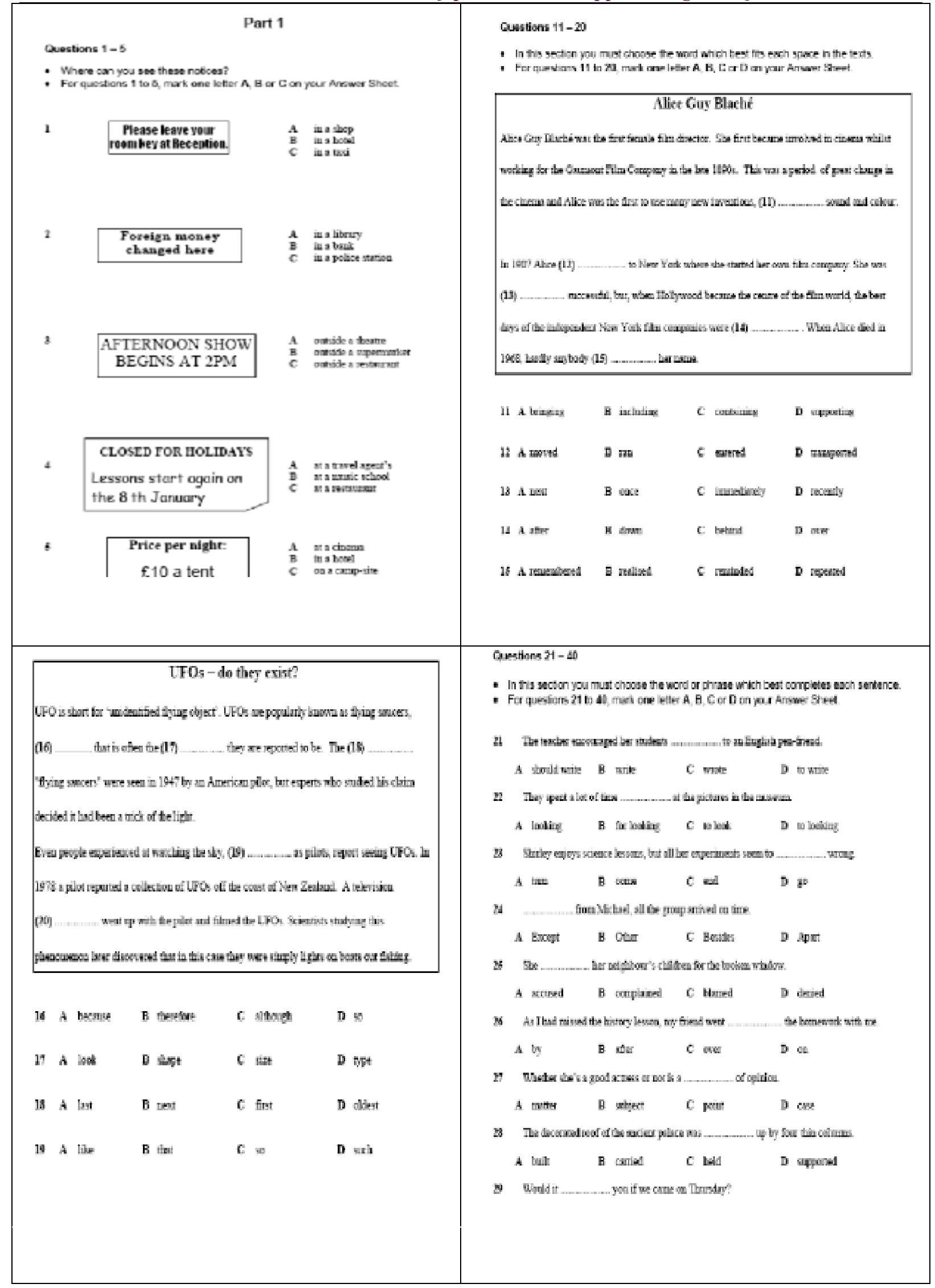


International Journal of Applied Linguistics \& English Literature

ISSN 2200-3592 (Print), ISSN 2200-3452 (Online)

Vol. 1 No. 7; November 2012 [Special Issue on Applied Linguistics]

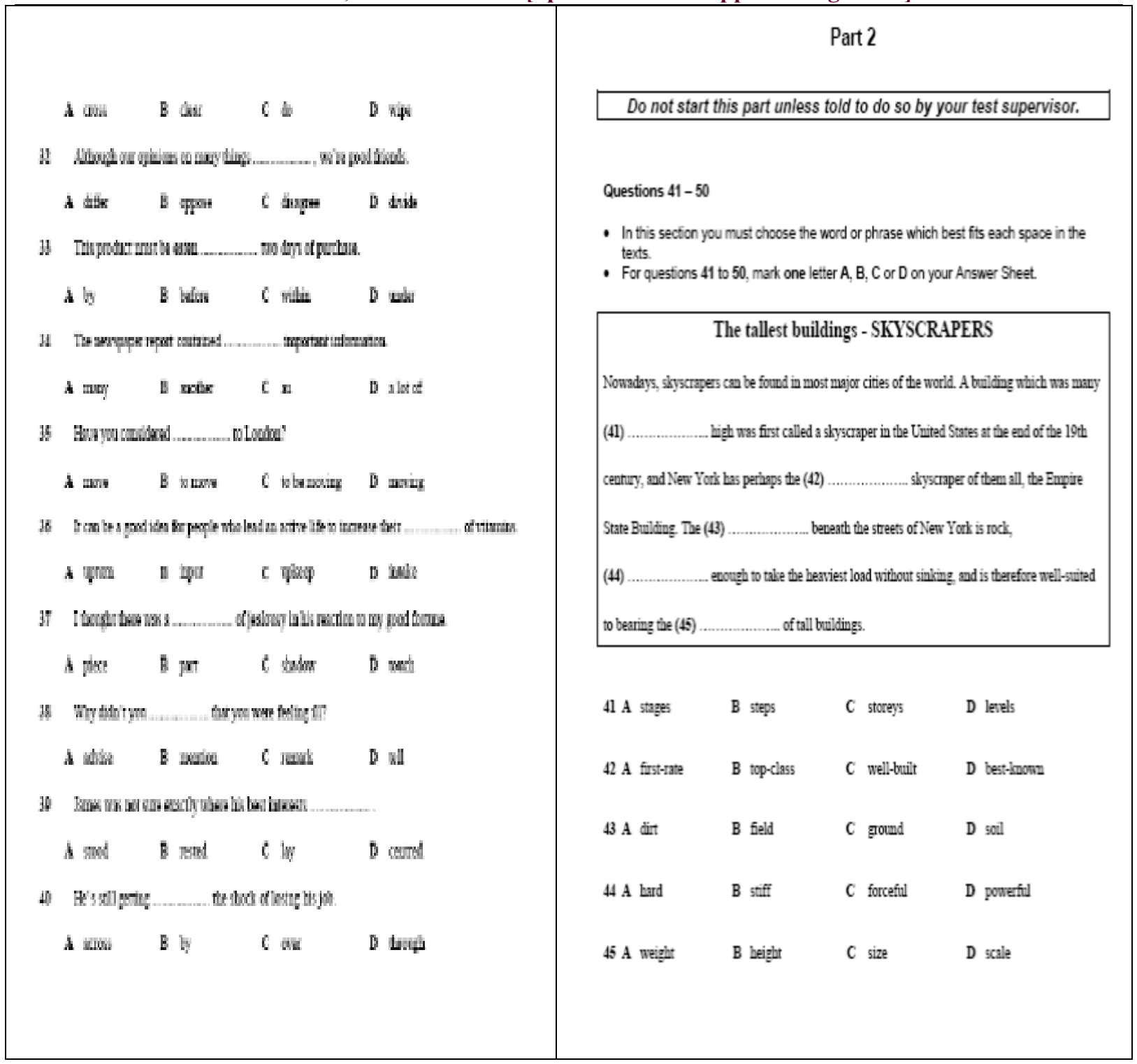


International Journal of Applied Linguistics \& English Literature

ISSN 2200-3592 (Print), ISSN 2200-3452 (Online)

Vol. 1 No. 7; November 2012 [Special Issue on Applied Linguistics]

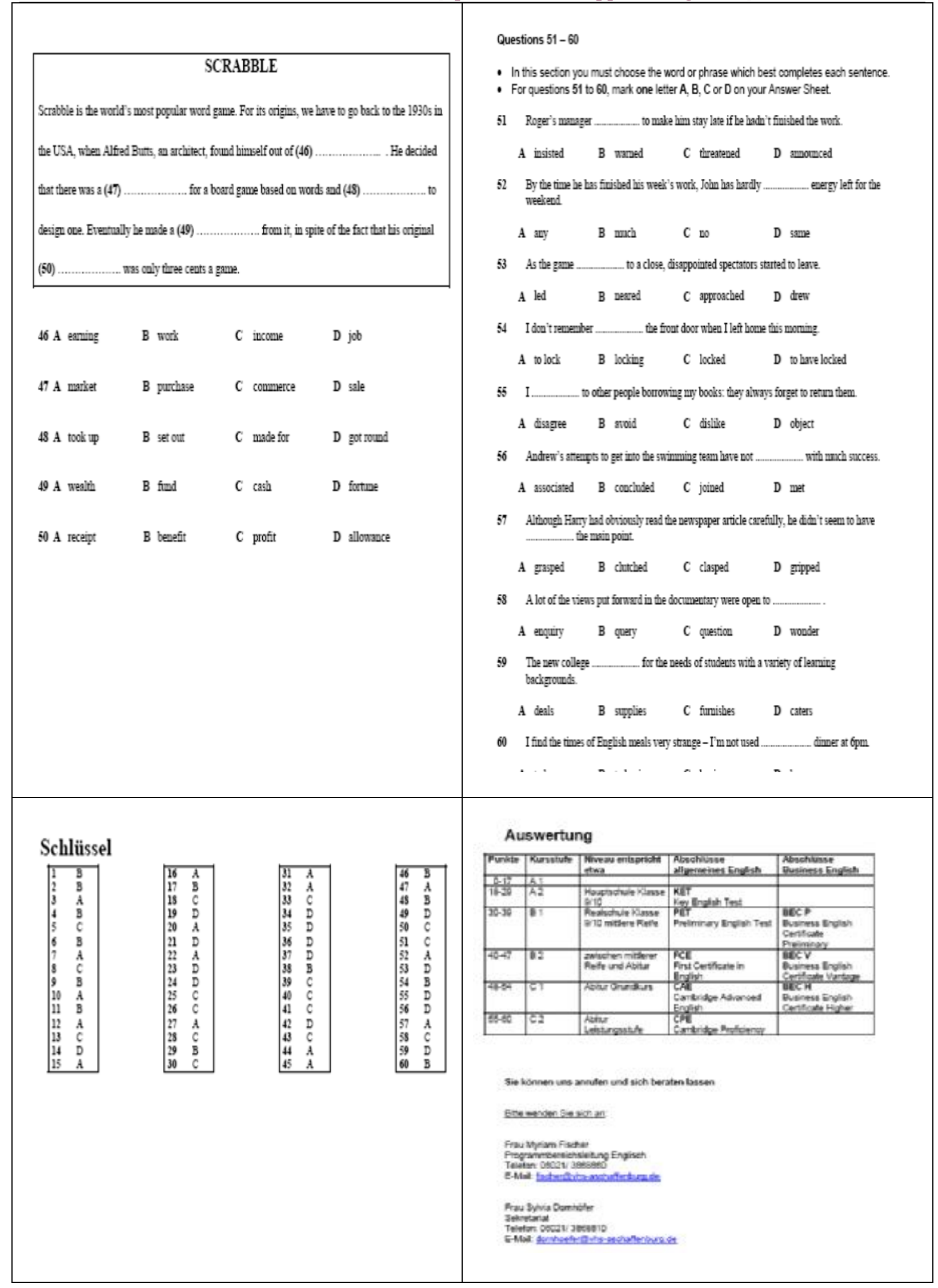


Appendix 2

Roebuck's Analytic scoring Rubrics modified by Maftoon\&Rabiee (2006)

Scoring Rubric for composition

\section{Vocabulary \\ Comments for improvements}

- Completely accurate and appropriate, no errors

- Usually accurate and appropriate, few minor errors

- Frequently accurate ,occasional inaccuracies

- Not extensive enough, frequent inaccuracies, limited vocabulary

- Completely inadequate and inaccurate, lots of major errors

II. Grammar

4

Comments for improvement:

- Complete mastery over grammar, variety in sentence structure and lengths, no errors

- May contain few errors that do not interfere with comprehensibility

- Some minor errors that may interfere with comprehensibility, some control of major patterns

- Many errors that interfere with comprehensibility, little control of major patterns

- Almost all grammatical patterns incorrect, lots of major errors leading to complete in comprehensibility

\section{Organization}

1

2 3

Comments for improvement

- Relevant, fully informative; adequate level of creativity and detail; well-organized, logical

- Generally informative, may lack some creativity and detail

- Usually informative; occasional lapses in organization and/or coherence

- Incomplete; lacks important information and creativity; poorly developed, lacks coherence

- Not informative, provides little or no information, lacking key components, organized incoherently

IV. Mechanics

1

4

Comments for improvement:

- Completely accurate and appropriate, no errors

- Generally accurate, few minor errors

- Usually accurate, frequent inaccuracies not interfering with comprehensibility

- Usually inaccurate, interfering with comprehensibility

- Completely inaccurate, lots of major errors

Note:

5. No errors

4. 1-3 errors

3. 4-6 errors

2. 7-9 errors

1. 10 and over 